\title{
Mikrobiota jelitowa a leki. Interakcje wpływające na skuteczność i bezpieczeństwo farmakoterapii
}

Gut microbiota and drugs. Interactions influencing the efficacy and safety of pharmacotherapy.

Joanna Nycz, Alicja Zajdel ${ }^{\star}$

Katedra i Zakład Biofarmacji, Wydział Nauk Farmaceutycznych w Sosnowcu, Śląski Uniwersytet Medyczny w Katowicach

Abstrakt

Mikrobiota jelitowa stanowi nieodłączny element organizmu umoźliwiający jego prawidłowe funkcjonowanie. Dzięki mikroorganizmom jelitowym możliwa jest stymulacja układu odpornościowego, synteza witamin czy poprawa wchłaniania składników odżywczych. Jednak jej aktywność może również niekorzystnie działać na organizm, m.in. z powodu przetwarzania treści jelitowej. Opisywana w artykule interakcja mikrobiota-lek uwzględnia pozytywny i negatywny wpływ mikroorganizmów jelitowych na farmakoterapię poprzez bezpośrednie i pośrednie oddziaływanie na lek w organizmie. Ze względu na to, że mikrobiom stanowi nieodłączny element organizmu, ingerencja nawet w jego niewielką część może doprowadzić do wystąpienia daleko idących, czasami niespodziewanych skutków. Stąd w celu poprawy skuteczności i bezpieczeństwa farmakoterapii konieczne jest wyjaśnienie mechanizmów oddziaływania mikrobioty na lek w organizmie.

W artykule podsumowano obecną wiedzę na temat biologicznej aktywności mikrobioty jelitowej, a zwłaszcza oddziaływań mikrobiota-leki determinujących skuteczność i bezpieczeństwo farmakoterapii. Wyszukiwanie przeprowadzono we wrześniu 2020 r. w bazach danych PubMed, Scopus, Web of Science, Cochrane Library i powszechnie dostępnej literaturze z użyciem terminów: „mikrobiota jelitowa”, „mikrobiom”, „metabolizm leku”, „interakcje mikrobiota-lek”. W artykule omówiono interakcje między mikrobiotą a lekami m.in. z grupy antybiotyków, inhibitorów pompy protonowej, sulfonamidów, pochodnych kwasu 5-aminosalicylowego, niesteroidowych leków przeciwzapalnych, przeciwnowotworowych, statyn czy metforminą.

Słowa

kluczowe mikrobiota jelitowa • biotransformacja leku • interakcje mikrobiota jelitowa-leki

Otrzymano: 16.09.2020, Zaakceptowano: 08.04.2021

Abstract

The intestinal microbiota is an integral part of the body that enables its proper functioning. Owing to intestinal microorganisms it is possible to stimulate the immune system, synthesize vitamins and improve the absorption of nutrients. However, its activity may also have adverse effects on the body, resulting e.g. from the processing of the intestinal contents. The microbiota-drug interaction described in this article is based on the positive and negative effects of intestinal microorganisms on pharmacotherapy by directly and indirectly influencing the fate of the drug in the body. Due to the fact that the microbiome is an inseparable element of the body, interfering with even a small part of it can lead to farreaching, sometimes unexpected effects. Hence, in order to improve the efficacy and safety of pharmacotherapy, it is necessary to explain the mechanisms of microbiota's influence on the fate of the drug in the body.

The article summarizes the current knowledge on the biological activity of the intestinal microbiota, in particular on the interactions of microbiota and drugs that determine the effectiveness and safety of pharmacotherapy. A search was performed in September 2020 in the databases Pubmed, Scopus, Web of Science, Cochrane Library, and gray literature using the terms: "gut microbiota", "microbiome", "drug metabolism", "gut microbiota-drug interactions". The article discusses the interactions between the microbiota and drugs, including the group of antibiotics, proton pump inhibitors, sulfonamides, 5-aminosalicylic acid derivatives, non-steroidal anti-inflammatory drugs, anti-cancer drugs, statins or metformin.

\section{Keywords}

gut microbiota $\cdot$ drug metabolism • gut microbiota-drug interactions

Received: 16.09.2020, Accepted: 08.04.2021

*Corresponding author e-mail: azajdel@sum.edu.pl

() Br:Nc-ND ( 2021 Nycz, Zajdel, This work is licensed under the Creative Commons Attribution-NonCommercial-NoDerivs 4.0 License. 


\section{Wprowadzenie}

Wraz z postępem medycyny i nauki, a zwłaszcza biologii molekularnej, coraz wyraźniej widać różnice w odpowiedzi na farmakoterapię między pacjentami. Skuteczność farmakoterapii zależy od wielu czynników, m.in. uwarunkowań genetycznych, wieku, diety. W tym kontekście należy zwrócić uwagę na rolę mikroorganizmów jelitowych (mikrobiota) mających własny metabolizm i w sumie około 150 razy więcej genów w porównaniu z genomem człowieka [1]. Mikrobiota jelit może tworzyć 1,5-2 kg masy ciała człowieka, a liczba komórek bakteryjnych może równać się liczbie komórek somatycznych organizmu [2]. Wpływ mikroorganizmów jelitowych na przemiany związków opisano w przypadku kilkudziesięciu powszechnie stosowanych leków [3, 4]. Stąd, nie bez powodu, w ciągu ostatnich lat można zaobserwować bardzo duży wzrost zainteresowania wpływem mikrobioty jelit na skuteczność farmakoterapii.

Mimo że mikrobiota jelitowa nie pochodzi od komórek człowieka, to, podobnie jak inne organy, pełni niezbędne funkcje dla zachowania zdrowia, a zachwianie jej równowagi może doprowadzić do zaburzenia ogólnej homeostazy organizmu. Mikrobiotę jelit reprezentują głównie przedstawiciele rodzajów: Actinomyces, Bacteroides, Firmicutes i Proteobacteria. Ich zawartość jest dość stabilna u dorosłej osoby, a odmienne warunki środowiskowe w poszczególnych odcinkach jelit warunkują zróżnicowanie jej składu. Zakłada się, że $30 \%$ zespołu mikroorganizmów jelitowych to stabilny, niezmienny skład jakościowy i ilościowy, który jest charakterystyczny dla danego człowieka, natomiast pozostałe $70 \%$ może podlegać modyfikacjom związanym ze stylem życia, dietą i uwarunkowaniami patofizjologicznymi [2]. Wydaje się, że w przyszłości indywidualny skład mikroorganizmów jelitowych określany w oparciu o analizy metagenomowe może stać się jednym ze sposobów identyfikowania ludzi [5].

Wśród czynników wpływających na mikrobiotę jelit można wyróżnić: wiek, środowisko, stres, zaburzenia hormonalne, masę ciała, dietę oraz stosowane leki [6, 7, 8, 9] (ryc. 1). W ostatnich latach coraz częściej zauważa się, że skład mikrobioty jelitowej może być czynnikiem wpływającym na bilans energetyczny organizmu. Jednak dotąd nie wyjaśniono, czy różnice w składzie mikrobioty jelitowej u osób otyłych są skutkiem nieprawidłowej diety, która doprowadziła do nadmiernej masy ciała, czy też obecność konkretnych mikroorganizmów jelitowych odpowiada za zwiększoną predyspozycję do rozwoju otyłości [8]. Kompozycja jakościowa i ilościowa mikroorganizmów jelitowych zmienia się wraz z wiekiem człowieka i środowiskiem, w jakim przebywa. Szczególne znaczenie mają tutaj dwa okresy w życiu człowieka: niemowlęcy, który charakteryzuje się nie w pełni wykształconą, podatną na zmiany mikrobiotą jelitową, oraz starości, której towarzyszy zmniejszenie różnorodności składu zespołu mikroorganizmów, a nawet występowanie dysbiozy [9, 10, 11, 12, 13]. Efekty te można powiązać ze zmianami diety, stylu życia, a także stosowaniem polifarmakoterapii [7, 14, 15]. U noworodków prawidłowy rozwój mikrobioty jelitowej jest niezbędny do wykształcenia układu odpornościowego, a w tym bariery jelitowej. Stąd od rodzaju porodu, trybu karmienia i innych czynników, takich jak antybiotykoterapia, może zależeć, czy dziecko będzie predysponowane do zaburzeń immunologicznych [12, 13, 16]. Odpowiednio zbilansowane odżywianie i aktywność fizyczna są niezbędne do zachowania równowagi organizmu, dlatego nie można kwestionować wpływu stylu życia na zespół mikroorganizmów jelitowych. Tezę potwierdzają obserwacje mniejszego zróżnicowania mikrobioty jelitowej u ludzi otyłych w porównaniu ze sportowcami [7].

Jedną z podstawowych funkcji mikrobioty jest hamowanie kolonizacji jelit przez potencjalnie chorobotwórcze mikroorganizmy, co uzyskuje się m.in. przez obniżanie pH treści pokarmowej jelit, wydzielanie substancji o aktywności przeciwdrobnoustrojowej, konkurowanie o składniki odżywcze oraz miejsca wiązania się z nabłonkiem jelit. Istotną rolą mikrobioty jelitowej jest utrzymywanie szczelności bariery jelitowej m.in. przez stymulację komórek nabłonkowych do syntezy mucyn, które tworzą ochronną warstwę śluzową ścian jelita. Mikrobiota, uczestnicząc $\mathrm{w}$ trawieniu resztek pokarmowych, odpowiada za wytwarzanie witaminy $\mathrm{K}$, witamin z grupy B oraz pobudza absorpcję składników odżywczych, jonów wapnia, potasu, magnezu i żelaza. W wyniku fermentacji błonnika pokarmowego przez bakterie jelitowe, powstają korzystne dla zdrowia człowieka krótkołańcuchowe kwasy tłuszczowe (short chain fatty acids; SCFAs), takie jak: kwas octowy, propionowy i masłowy. Do prawidłowego funkcjonowania jelit szczególnie przyczynia się maślan, który jest wytwarzany przez Faecalibacterium prausnitzii, Eubacterium/Roseburia i niektóre gatunki Firmicutes. Jest głównym źródłem energii kolonocytów, co zapewnia ich prawidłowy metabolizm, proliferację i różnicowanie, a także korzystnie wpływa na motorykę jelit i ograniczenie wzrostu patogenów [17]. Wytwarzanie SCFAs i metabolitów tryptofanu umożliwia mikroorganizmom jelitowym oddziaływanie na układ odpornościowy. SCFAs prowadzą do wzrostu liczby komórek $\mathrm{T}$ regulatorowych, wykazujących działanie przeciwzapalne, co umożliwia zasiedlanie jelit przez bakterie komensalne, jednocześnie zapewniając ochronę przed patogenami. W zależności od rodzaju stymulowanego podtypu komórek T, dochodzi do regulacji odpowiedzi immunologicznej organizmu $[18,19]$. W przypadku przewagi bakterii patogennych w składzie mikrobioty jelitowej dochodzi do powstania reakcji zapalnej. Stan równowagi w jelitach osiągany jest, gdy układ odpornościowy wykazuje pewną nadwrażliwość, podczas której jest tolerowana obecność bakterii komensalnych [20]. 

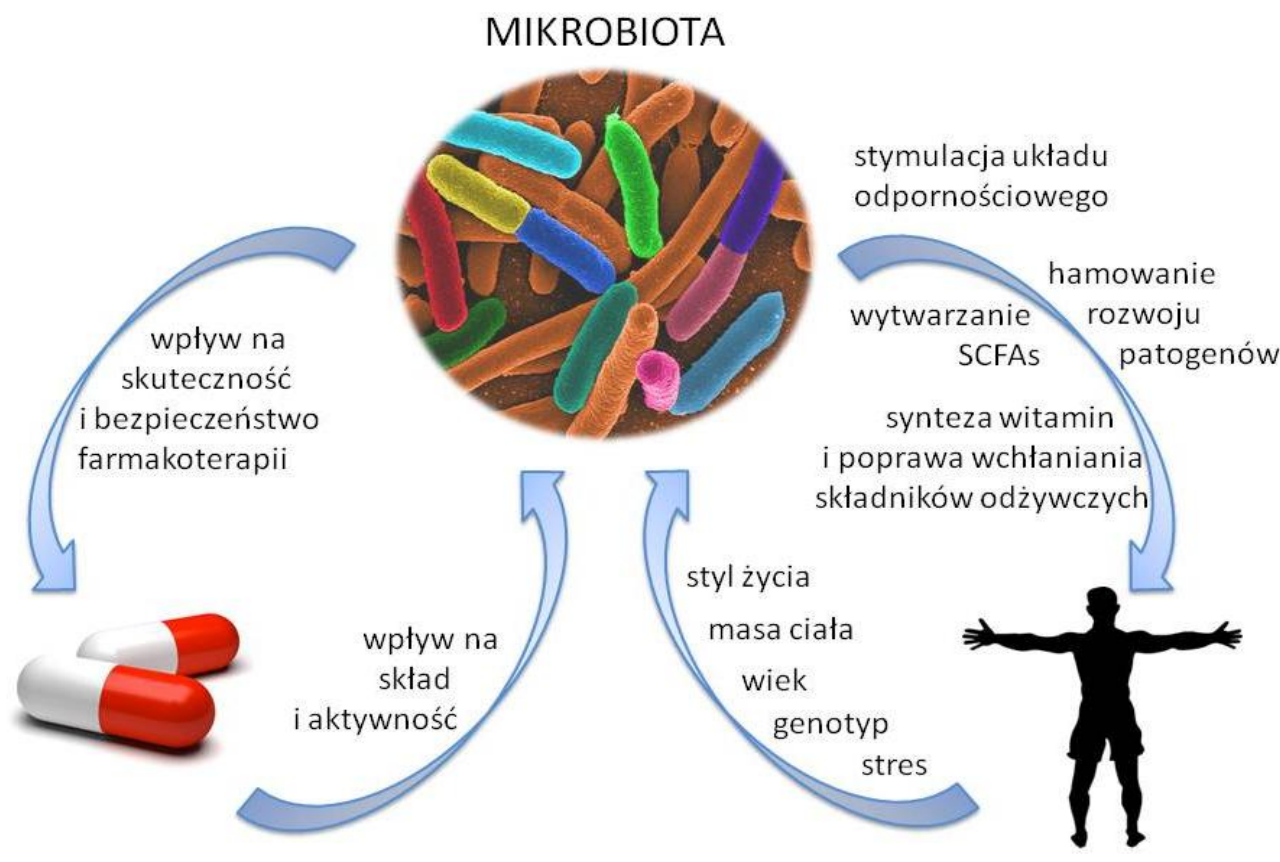

Rycina 1. Interakcje mikrobiota jelitowa-leki oraz mikrobiota jelitowa-organizm człowieka

Mikrobiota jelit przyczynia się także do utrzymania zdrowia organizmu gospodarza przez syntezę drugorzędowych kwasów żółciowych, których rola nie ogranicza się tylko do zapewnienia prawidłowego wchłaniania lipidów i witamin, lecz ze względu na to, iż są ligandami receptorów FXR (farnesoid X receptor; receptor kwasu żółciowego) i TGR5 (G proteincoupled bile acid receptor; receptor kwasu żółciowego sprzężony z białkiem $\mathrm{G}$ ) mogą także pośredniczyć w regulacji metabolizmu glukozy, lipidów i kwasów żółciowych [21].

Mikrobiota jelitowa wpływa na funkcjonowanie układu nerwowego, przez zdolność do wytwarzania oraz możliwość regulowania dostępności substratów do syntezy neuroprzekaźników, m.in. serotoniny, dopaminy, norepinefryny, 5-hydroksytryptaminy, acetylocholiny, kwasu gamma-aminomasłowego, pochodnych tryptofanu (tryptamina i kynureina) [22, 23]. Dowiedziono, że maślan może wpływać na uwalnianie serotoniny $z$ komórek enterochromafinowych jelit [24], a także ze względu na to, iż jest niespecyficznym inhibitorem deacetylaz histonowych, biorących udział w formowaniu pamięci, może wpływać na proces zapamiętywania oraz plastyczność synaptyczną [25]. Natomiastpropionian chronibarierękrew-mózg przed skutkami stresu oksydacyjnego, przez wpływ na ekspresję genów kodujących białka wykazujące aktywność antyoksydacyjną [26]. Zależności między generowanymi przez mikroorganizmy jelitowe metabolitami a funkcjonowaniem ośrodkowego układu nerwowego, określono jako dwukierunkową oś jelitamózg, ponieważ zaburzenia funkcjonowania obu elementów mogą wzajemnie na siebie oddziaływać [22]. Przykładem takich zaburzeń jest zespół jelita nadwrażliwego (irritable bowel syndrome, IBS), w przebiegu którego dochodzi do zaburzeń przepuszczalności bariery jelitowej i składu mikrobioty jelitowej w wyniku stresu [27]. Dlatego zaczęto szukać odpowiedzi na pytanie, czy dysbioza, podobnie jak w przypadku chorób zapalnych jelit, nowotworów jelit, otyłości i cukrzycy [28, 29, 30, 31], może być podłożem chorób, takich jak depresja czy choroba Parkinsona [22].

Oprócz opisanego wyżej korzystnego wpływu mikrobioty jelitowej na stan zdrowia należy też wspomnieć o potencjalnie niekorzystnych skutkach jej aktywności na przykładzie przetwarzania składników odżywczych. Niezbędne do wzrostu mikroorganizmów białka z pożywienia mogą być metabolizowane do poliamin, N-nitrozozwiązków, siarkowodoru i amoniaku, które w nadmiarze mogą uszkadzać barierę jelitową oraz wykazywać działanie cytotoksyczne, genotoksyczne i karcynogenne [32, 33]. Natomiast przy nadmiernej podaży nasyconych kwasów tłuszczowych $w$ treści pokarmowej jelit zauważono m.in. zwiększenie zawartości Clostridium XI/XIV, czego skutkiem jest wytwarzanie związków prozapalnych i genotoksycznych, takich jak kwas dezoksycholowy [34]. 
Inne niepożądane działanie mikrobioty jelitowej jest związane z dużą aktywnością $\beta$-glukuronidazy i $\beta$-glukozydazy (szczególnie u bakterii z rodzaju Clostridium) $[35,36]$. Wytwarzanie toksycznych produktów metabolizmu mikroorganizmów jelitowych powiązano m.in. z rozwojem stanów patologicznych, takich jak rak jelita grubego czy choroba zapalna jelit.

\section{Wpływ leków na mikrobiotę jelit}

Dla składu i funkcjonowania mikrobioty jelitowej istotne znaczenie ma stosowana farmakoterapia. Niedawno opublikowane badania wskazują, że zwłaszcza silny wpływ na mikroorganizmy jelitowe wykazuje antybiotykoterapia, inhibitory pompy protonowej (IPP), metformina oraz środki przeczyszczające [37]. W licznych badaniach podejmowano próby wyjaśnienia wpływu niedoboru żelaza i jego suplementacji na mikrobiotę jelitową. Zauważono, że preparaty żelaza podawane doustnie mają bezpośredni wpływ na zmiany składu mikroorganizmów w jelitach, co może spowodować zmniejszenie pożytecznej mikrobioty oraz stanowić okazję do ekspansji patogenów jelitowych [38]. Wiadomo, że niekorzystne działanie leków przeciwpsychotycznych II generacji objawiające się zaburzeniami metabolicznymi jest związane z ich wpływem na mikrobiotę jelitową [39]. Wiadomo, że zastosowanie antybiotyków w celu usunięcia bakterii patogennych jednocześnie narusza bardzo złożone mikrośrodowisko jelit, w tym wzajemne odżywianie bakterii komensalnych (cross-feeding), i wywołuje dysbiozę. Ponadto antybiotykoterapia wiąże się z ryzykiem rozwoju lekooporności bakterii, co może doprowadzić do zmiany składu mikrobioty. Dlatego do następstw antybiotykoterapii należy zaliczyć również zaburzenia syntezy istotnych dla zdrowia człowieka metabolitów bakterii, takich jak SCFAs czy drugorzędowe kwasy żółciowe, które w warunkach fizjologicznych są elementem bariery ochronnej m.in. przed infekcją C. difficile i związaną z nią biegunką [40]. Jednak w odróżnieniu od większości antybiotyków zastosowanie niewchłaniającej się z przewodu pokarmowego ryfaksyminy alfa - antybiotyku makrolidowego o szerokim zakresie działania przeciwbakteryjnego - nie tylko eliminuje bakterie patogenne, działa przeciwzapalnie, ale korzystnie moduluje skład mikrobioty jelitowej, co przywraca stan eubiozy jelitowej. Ta dodatkowa właściwość może być korzystna terapeutycznie w określonych warunkach klinicznych [41].

Oprócz większości antybiotyków niekorzystne efekty opisywane są również w przypadku IPP, których stosowanie wiąże się ze zmianą pH w świetle jelit i ryzykiem kolonizacji bakteriami pochodzącymi z jamy ustnej. W wyniku zmniejszenia kwasowości soku żołądkowego związanego z mechanizmem działania IPP może dochodzić do nadkażenia
C. difficile, chociaż wyniki dużego, prospektywnego, randomizowanego badania $z$ próbą placebo wskazują, że ryzyko wystąpienia zakażeń jelitowych nie jest zbyt wysokie [42, 43, 44]. Dowiedziono także, że IPP mogą przyspieszać starzenie śródbłonka jelit, chociaż rola mikrobioty pozostaje nierozpoznana w tym niepożądanym zjawisku [45]. W przeciwieństwie do antybiotyków oraz IPP, metformina, popularny lek stosowany m.in. w terapii cukrzycy typu 2, korzystnie wpływa na mikrobiotę jelitową przez zwiększenie udziału bakterii wytwarzających SCFAs. Jednak stymulowany przez metforminę wzrost Escherichia coli może być przyczyną występowania działań niepożądanych ze strony przewodu pokarmowego [46, 47]. Korzystne efekty w stosunku do mikrobioty jelitowej zauważono także podczas terapii statynami, co wiąże się z rzadszym występowaniem dysbiozy [48].

\section{Mikrobiota jelitowa a skuteczność i bezpieczeństwo farmakoterapii}

Jednym z wyzwań współczesnych terapii jest zapewnienie skuteczności i bezpieczeństwa farmakoterapii, co wiąże się z indywidualnym doborem schematów leczenia dla każdego pacjenta. W tym aspekcie istotne jest poznanie oraz uwzględnianie podczas planowania farmakoterapii $u$ indywidualnych chorych wpływu mikrobioty jelitowej na lek w organizmie. Zmiana składu jakościowego i ilościowego mikrobioty jelitowej może bezpośrednio wpływać na aktywność jej enzymów, a przez to może zmieniać farmakokinetykę i toksyczność stosowanych leków [49]. Przeważa pogląd, że poziom odpowiedzi na lek wynosi w granicach $50-75 \%$, co może być związane nie tylko z występowaniem polimorfizmów genów człowieka, ale także ze zmianami ekspresji genów spowodowanymi procesami chorobowymi jak i aktywnością mikrobioty [50, 51].

Po podaniu doustnym, w zależności od właściwości fizykochemicznych cząsteczek leku, substancje lecznicze mogą ulegać absorpcji w górnej części jelita cienkiego lub mieć przedłużony czas przebywania w przewodzie pokarmowym i docierać do jelita grubego, np. substancje lecznicze niecałkowicie uwolnione z postacileku. Przebywanie substancji leczniczych w jelitach zwiększa prawdopodobieństwo ich biotransformacji $z$ udziałem enzymów mikrobioty jelitowej. Mimo że jelito cienkie charakteryzuje się mniejszą zawartością mikroorganizmów w porównaniu do jelita grubego, jego potencjał do biotransformacji leków jest istotny, ponieważ w jego świetle obecne są bakteryjne enzymy CYP. Stąd badania czerpiące informacje o wpływie mikrobioty na biotransformację leku tylko na podstawie próbek kału powinny uwzględniać margines błędu w postaci metabolizmu w jelicie 
cienkim, który nie jest łatwy do określenia z powodu trudności związanych z pobraniem materiału [4, 52].

\section{Biotransformacja leków z udziałem enzymów mikrobioty jelitowej}

$\mathrm{Na}$ przestrzeni wieków mikroorganizmy jelitowe metabolizowały napotykane coraz to nowe związki chemiczne pojawiające się wraz z rozwojem przemysłu i postępem medycyny. Prawdopodobnie zdolność do przetwarzania ciągle poszerzającego się spektrum związków, zarówno przez bakterie jak i człowieka, wynika z właściwości enzymów mających powinowactwo do różnorodnych substratów [53]. Taka elastyczność funkcjonalna enzymów umożliwia koegzystencję mikroorganizmów i gospodarza, gdyż zapewnia wzajemną tolerancję na wytwarzane metabolity. Jednak niewielka swoistość substratowa enzymów ludzkich i mikrobioty powoduje, że mogą wykazywać powinowactwo do tych samych związków.

Zespół mikroorganizmów jelitowych może oddziaływać bezpośrednio lub pośrednio na biotransformację leków, zwłaszcza przyjmowanych doustnie (ryc. 2). Również leki podawane donaczyniowo mogą być substratami dla enzymów mikrobioty, gdyż wątrobowe produkty biotransformacji często są wydalane z żółcią do światła jelita. Najistotniejszymi enzymami mikrobioty jelitowej uczestniczącymi w przemianach substancji leczniczych są $\beta$-glukuronidazy, azoreduktazy, liazy, nitroreduktazy. W odróżnieniu od procesów biotransformacji substancji leczniczych w organizmie człowieka, gdzie dominują procesy utleniania i koniugacji, głównymi reakcjami przeprowadzanymi z udziałem enzymów mikrobioty są reakcje redukcji i hydrolizy. We względnie beztlenowych warunkach jelita redukcyjny metabolizm ksenobiotyków może ułatwiać oddychanie beztlenowe przez rozszerzenie zakresu alternatywnych akceptorów elektronów. Jednak hydroliza bezpośrednio dostarcza substratów do wzrostu mikroorganizmów. Na przykład wiele składników diety jest glikozylowanych, a ich hydroliza uwalnia cukry, które mogą zostać włączone do szlaku glikolizy [54, 55]. Bezpośrednie oddziaływanie enzymów mikrobioty jelitowej na substancje lecznicze lub ich metabolity może prowadzić do ich aktywacji, np. gdy substratem są proleki, inaktywacji czy wytworzenia toksycznych pochodnych. Pośredni wpływ mikrobioty jelitowej na biotransformację leków może być związany z oddziaływaniem metabolitów mikroorganizmów na aktywność ludzkich enzymów i białek transportowych uczestniczących w przemianach substancji leczniczych czy ekspresję genów determinujących przemiany leku w organizmie człowieka, a także na układ odpornościowy [47, 56, 57, 58].

Metabolity mikroorganizmów jelitowych, np. drugorzędowe kwasy żółciowe, tryptamina, mogą regulować ekspresję ludzkich genów kodujących białka I, II i III fazy biotransformacji, gdyż są ligandami czynników transkrypcyjnych i receptorów

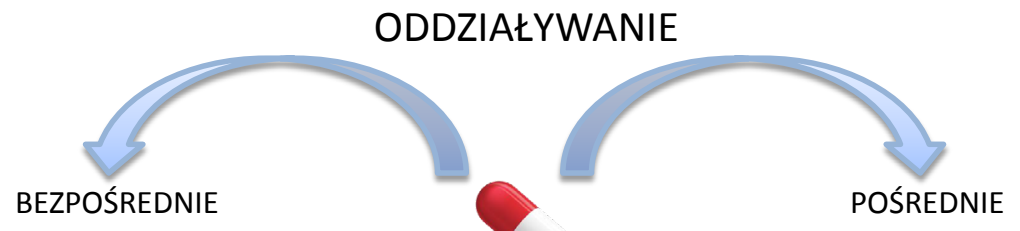

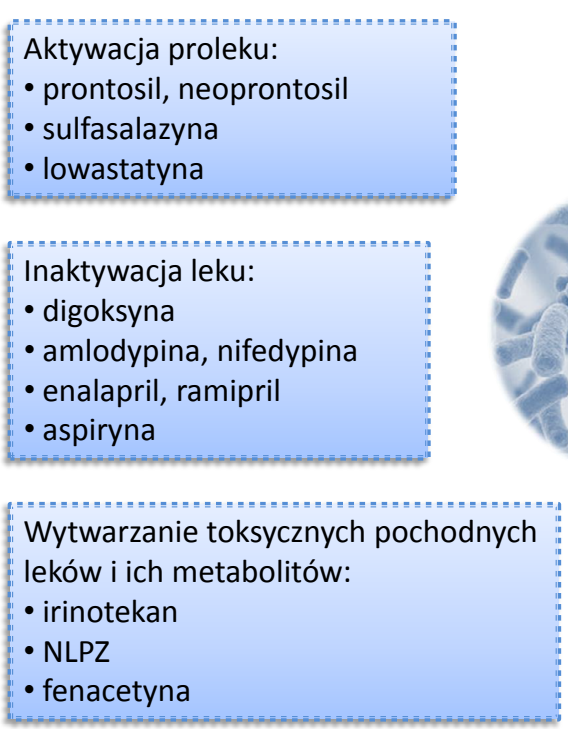

Metabolity bakteryjne, m.in.
drugorzędowe kwasy żółciowe,
tryptamina
regulacja ekspresji genów
kodujących białka I, II i III
fazy biotransformacji:
- ligandy AhR, CAR, PXR
regulacja aktywności
transporterów:
- simwastatyny
konkurowanie o miejsca
aktywne ludzkich enzymów
metabolizujących lek:
- DPD, SULT

Rycina 2. Mechanizmy bezpośredniego i pośredniego oddziaływania mikrobioty jelitowej na losy leku w organizmie 
jądrowych, m.in. PXR (receptora pregnanu X), CAR (konstytutywnego receptora androstanu), AhR (receptora węglowodorów aromatycznych), FXR i TGR5 [21, 59, 60, 61, 62]. Ponadto metabolity mikroorganizmów mogą także wpływać na farmakokinetykę substancji leczniczych, np. przez konkurowanie o miejsca aktywne enzymów uczestniczących w biotransformacji leków [63, 64, 65]. W dalszej części pracy opisano znaczenie kliniczne wpływu mikrobioty jelitowej na lek w organizmie człowieka.

\section{Korzystny wpływ mikrobioty jelitowej na skuteczność substancji leczniczych}

W przypadku niektórych leków będących prolekami, np. sulfonamidów (prontosilu i neoprontosilu) oraz pochodnych kwasu 5-aminosalicylowego (sulfasalazyny, olsalazyny, ipsalazyny i balsalazyny), aktywność metaboliczna mikrobioty jelitowej warunkuje ich działanie. Aktywacja tych proleków w jelicie polega na redukcji wiązania azowego przez bakteryjne azoreduktazy szczepów Bacteroides sp., Streptococcus faecalis, Lactobacillus sp. i uwolnienie aktywnych związków [66]. Niemniej często trudno jednoznacznie określić rolę przemian substancji leczniczych przez mikroorganizmy jelitowe w ostatecznym efekcie terapeutycznym. Przykładowo aktywny kwas 5-aminosalicylowy może stanowić substrat dla bakteryjnej $\mathrm{N}$-acetylotransferazy arylaminowej, co prowadzi do jego inaktywacji [67].

Zauważono, że mikrobiota jelitowa może zwiększać biodostępność leków podawanych doustnie. Odpowiedź pacjentów na simwastatynę wydaje się dodatnio skorelowana z poziomem drugorzędowych kwasów żółciowych. Dokładny mechanizm tego zjawiska nie jest dobrze poznany, jednak przeważa pogląd, że zwiększone wchłanianie simwastatyny może być związane z bezpośrednim zwiększeniem aktywności transporterów simwastatyny i kwasów żółciowych, pobudzeniem ich transkrypcji przez drugorzędowe kwasy żółciowe bądź bezpośrednią konkurencją pierwszo- i drugorzędowych kwasówżółciowycho dostęp do transporterów [68]. Lowastatyna, ze względu na laktonową budowę łatwo ulega hydrolizie do bardziej aktywnego hydroksykwasu. Wyniki badań z wykorzystaniem modelu zwierzęcego, w których szczurom przed zastosowaniem lowastatyny podano antybiotyki w celu zmniejszenia aktywności mikrobioty, wykazują nawet $50 \%$ obniżenie parametrów opisujących biodostępność (AUC i Cmax) hydroksykwasu. Obserwacje te potwierdzają istotny wpływ zaburzeń różnorodności mikroflory jelit na efektywność farmakoterapii i mogą tłumaczyć różnice w odpowiedzi na lek między pacjentami [69].

Korzystny wpływ mikrobioty można także zauważyć podczas terapii z zastosowaniem cyklofosfamidu czy metforminy. Cyklofosfamid, lek o właściwościach alkilujących, powoduje immunogenną śmierć komórek nowotworowych. Zauważono, że w czasie stosowania cyklofosfamidu niektóre gatunki bakterii mogą ulegać przemieszczeniu z jelit do wtórnych narządów limfoidalnych, co wzmacnia działanie leku przez pobudzanie wytwarzania komórek T pomocniczych (TH1 i TH17) [70, 71]. Natomiast terapii z użyciem metforminy towarzyszy zwiększenie w jelitach ilości Akkermansia muciniphila, których obecność wspiera działanie przeciwcukrzycowe metforminy przez nasilenie metabolizmu glukozy [47]. Uważa się także, że prawidłowy skład mikrobiomu jelitowego może być jednym z czynników determinujących skuteczność immunoterapii w nabłonkowych nowotworach i czerniakach [57, 58].

\section{Negatywny wpływ mikrobioty jelitowej na skuteczność substancji leczniczych}

Mikrobiota jelitowa przez działanie na lek w organizmie może się przyczyniać do nasilenia niekorzystnych dla organizmu gospodarza skutków farmakoterapii. Ze względu na to, iż dominującym procesem II fazy biotransformacji u ludzi jest sprzęganie substancji leczniczych lub ich metabolitów z kwasem glukuronowym, a wytworzone glukuronidy często wraz z żółcią są wydzielane do światła jelita, gdzie są substratami bakteryjnych $\beta$-glukuronidaz, reakcje dekoniugacji mogą odpowiadać za nasilenie działań toksycznych bądź zwiększać stężenie leków w krwi. Do najlepiej poznanych i często opisywanych przykładów należą przypadki zwiększenia toksyczności terapii z zastosowaniem irinotekanu czy leków z grupy niesteroidowych leków przeciwzapalnych (NLPZ). Irinotekan, lek przeciwnowotworowy, podawany dożylnie, w obecności karboksyloesterazy ulega przekształceniu do aktywnego metabolitu SN-38, który w wątrobie ulega sprzęganiu z aktywnym kwasem glukuronowym. Nieaktywny glukuronid SN-38 wydalany jest z żółcią do światła jelita. W wyniku reakcji dekoniungacji ponownie uwalniany jest aktywny SN-38, wykazujący silne działanie cytotoksyczne w stosunku do komórek nabłonkowych jelit [72]. Podobne efekty opisywano w przypadku NLPZ, szczególnie zawierających ugrupowanie karboksylowe (diklofenak, indometacyna, ketoprofen), którego obecność wiąże się z łatwiejszym wytwarzaniem glukuronidów. Podobnie jak glukuronid SN-38, glukuronidy NLPZ mogą ulegać dekoniungacji w jelicie, co przyczynia się do nasilenia toksyczności i rozwoju enteropatii [73]. Również leki z grupy sartanów (losartan, kandesartan, irbesartan) są usuwane $z$ organizmu w postaci glukuronidów. W świetle jelita, z udziałem bakteryjnych $\beta$-glukuronidaz, $z$ glukuronidów uwalniane są substancje lecznicze, które mogą ulegać ponownemu wchłanianiu w jelicie, a to zwiększa ich stężenia we krwi [74].

Opisywano także przypadki inaktywacji leków przez mikrobiotę jelitową, co prowadzi do zmniejszenia biodostępności i w konsekwencji do zbyt niskich stężeń tych leków we krwi. Dobrze poznanym przykładem inaktywacji leku przez mikroorganizmy jelitowe jest reakcja redukcji 
digoksyny do nieaktywnej dihydrodigoksyny katalizowana przez reduktazę glikozydów nasercowych wytwarzaną przez bakterie Eggerthella lenta. Reakcja polega na rozkładzie pierścienia laktonowego digoksyny. Digoksyna, jak i inne glikozydy nasercowe, jest odpowiedzialna za aktywację bakteryjnego operonu kodującego reduktazę glikozydów nasercowych (operon cgr). Jednak nie wszystkie szczepy E. lenta mają ten operon, dlatego można wyróżnić szczepy metabolizujące i niemetabolizujące glikozydy nasercowe, co tłumaczy zmienność w odpowiedzi na lek u pacjentów. W przypadku szczepów metabolizujących digoksynę, jej podanie nasila ekspresję reduktazy przeprowadzającej reakcje inaktywacji digoksyny. Należy zwrócić uwagę, że dieta bogata w aminokwas - argininę - może zapobiegać indukcji operonu cgr $[75,76,77]$. Możliwość optymalizacji farmakoterapii przez wpływ na pojedynczy szczep bakterii mikrobiomu za pomocą diety wydaje się atrakcyjnym rozwiązaniem problemów związanych z niepożądanymi oddziaływaniami lek-mikrobiom. W przypadku farmakoterapii choroby Parkinsona, na jej skuteczność ma wpływ obecność pałeczek Helicobacter pylorii. Występujące na zewnętrznej błonie tych bakterii adhezyny są odpowiedzialne za wiązanie lewodopy (L-DOPA), przez co ograniczają jej dostępność do organizmu gospodarza. Ponadto $H$. pylorii może zmniejszać skuteczność terapii L-DOPA przez zmniejszenie jej wchłaniania w błonie śluzowej dwunastnicy, wytwarzania wolnych rodników tlenowych inaktywujących lek oraz przez jej bezpośredni metabolizm. Stąd eradykacja $H$. pylorii często zwiększa skuteczność terapii u pacjentów leczonych L-DOPA [78]. W wyniku aktywności mikroorganizmów jelitowych również w przypadku stosowania blokerów kanałów wapniowych, takich jakamlodypinainifedypina, będących substratamibakteryjnych dehydrogenaz, inhibitorów konwertazy angiotensyny takich jak enalapril i ramipril, będących substratami bakteryjnych esteraz, czy kwasu acetylosalicylowego obserwuje się zmniejszenie biodostępności i ich stężenia we krwi [74]. Stosowanie antybiotykoterapii może zmniejszać aktywność mikrobioty jelitowej i zwiększać biodostępność leków. Aspekt ten ma istotne znaczenie kliniczne w przypadku leków charakteryzujących się wąskim indeksem terapeutycznym, np. amiodaronu [79]. W przypadku leków o szerokim indeksie terapeutycznym, mimo znacznych zmian wartości parametrów farmakokinetycznych, interakcja antybiotyk-mikrobiota-lek, może mieć niezauważalny przebieg.

Istotnym problemem farmakoterapii są skutki interakcji między lekiem a produktami przemian mikrobioty jelitowej. Obserwowano, że paracetamol może działać toksycznie w obecności wysokich stężeń p-krezolu, który jest bakteryjnym metabolitem tyrozyny, wytwarzanym m.in. przez Clostridium difficile. P-krezol konkuruje z paracetamolem o miejsca aktywne sulfotransferaz (SULT) i transferaz urydynodifosfoglukuronowych (UGT), co może hamować detoksykację paracetamolu i spowodować nadmierne wytwarzanie hepatotoksycznego metabolitu - NAPQI (N-acetylo-4-benzochinonoiminy) [63, 65]. Nieprzewidziane interakcje leku z mikrobiotą jelitową mogą mieć także tragiczne skutki, np. wśród pacjentów onkologicznych leczonych 5-fluorouracylem (5-FU), którym jednocześnie podano lek przeciwwirusowy sorywudynę, zarejestrowano 18 zgonów. Nieodwracalna inhibicja wątrobowej dehydrogenazy dihydropirymidynowej (DPD) przez dihydrobromowinylouracyl, bakteryjny metabolit sorywudyny, spowodowała nieodwracalne zablokowanie biotransformacji 5-FU, a to doprowadziło do zwiększenia jego stężenia i zgonów pacjentów [80, 81].

Podejmowane są liczne próby ograniczania niekorzystnego wpływu mikrobioty jelitowej na farmakokinetykę leków, które obejmują nie tylko zastosowanie racjonalnej antybiotykoterapii, ale także selektywnych inhibitorów $\beta$-glukuronidaz czy błonnika pokarmowego. Innym przykładem jest możliwość modyfikacji składu mikrobioty jelitowej przez zastosowanie probiotyków, prebiotyków, synbiotyków, eubiotyków (ryfaksyminy), antybiotyków bądź transplantacji mikroorganizmów jelitowych, jednak metody te wymagają dalszych badań [82, 83, 84]. Korzyści ze stosowania inhibitora $\beta$-glukuronidazy obserwowano w badaniach na myszach leczonych irinotekanem. Zastosowanie inhibitora $\beta$-glukuronidazy zmniejszało biegunki oraz ograniczało stan zapalny komórek nabłonkowych jelit [72, 85]. Podobne rezultaty opisano $\mathrm{w}$ przypadku zapobiegania enteropatiom wywołanym przez NLPZ [73].

\section{Podsumowanie}

Wyjaśnienie mechanizmów oddziaływania mikrobioty na lek w organizmie stanowi podstawy do opracowania skutecznych strategii przeciwdziałania niepożądanym skutkom tych interakcji. Ze względu na to, że mikrobiom stanowi nieodłączny element organizmu, ingerencja w jego niewielką część może spowodować wystąpienie niespodziewanych skutków. Dlatego tak istotny jest postęp technologii medycznych umożliwiający ciągłe poznawanie nowych interakcji lek-mikrobiota, które są jednymi z czynników determinujących bezpieczeństwo i skuteczność farmakoterapii.

\section{Wykaz skrótów}

5-FU - 5-fluorouracyl; AhR - receptor węglowodorów aromatycznych; CAR - konstytutywny receptor androstanu; DPD - dehydrogenazy dihydropirymidynowe; FXR - receptor kwasu żółciowego (farnesoid $X$ receptor); IBS - zespół jelita nadwrażliwego (irritable bowel syndrom); IPP - 
inhibitory pompy protonowej; L-DOPA - lewodopa; NAPQI - N-acetylo-4-benzochinonoimina; NLPZ - niesteroidowe leki przeciwzapalne; PXR - receptor pregnanu X; SCFAs krótkołańcuchowe kwasy tłuszczowe (short chain fatty acids); SULT - sulfotransferazy; TGR5 - receptor kwasu żółciowego sprzężony $z$ białkiem $G$ ( $G$ protein-coupled bile acid receptor); UGT - transferazy urydynodifosfo-glukuronowe

\section{Finansowanie}

Praca powstała dzięki wsparciu finansowemu SUM, nr umowy: KNW-1-040/N/9/O

\section{Konflikt interesów}

Autorki deklarują brak potencjalnych konfliktów interesów.

\section{Piśmiennictwo}

[1] Zimmermann M., Zimmermann-Kogadeeva M., Wegmann R., Goodman A.L.: Mapping human microbiome drug metabolism by gut bacteria and their genes. Nature, 2019; 570: 462-467

[2] Turnbaugh P.J., Ley R.E., Hamady M., Fraser-Liggett C.M., Knight R., Gordon J.I.: The human microbiome project. Nature, 2007; 449: 804-810

[3] Swanson H.I.: Drug metabolism by the host and gut microbiota: A partnership or rivalry? Drug Metab. Dispos., 2015; 43: 1499-1504

[4] Wilson I.D., Nicholson J.K.: Gut microbiome interactions with drug metabolism, efficacy, and toxicity. Transl. Res., 2017; 179: 204222

[5] Franzosa E.A., Huang K., Meadow J.F., Gevers D., Lemon K.P., Bohannan B.J., Huttenhower C.: Identifying personal microbiomes using metagenomic codes. Proc. Natl. Acad. Sci. USA, 2015; 112: E2930-E2938

[6] Baker J.M., Al-Nakkash L., Herbst-Kralovetz M.M.: Estrogen-gut microbiome axis: Physiological and clinical implications. Maturitas, 2017; 103: 45-53

[7] Conlon M.A., Bird A.R.: The impact of diet and lifestyle on gut microbiota and human health. Nutrients, 2015; 7: 17-44

[8] Crovesy L., Masterson D., Rosado E.L.: Profile of the gut microbiota of adults with obesity: A systematic review. Eur. J. Clin. Nutr., 2020; 74, 1251-1262

[9] Hopkins M.J., Sharp R., Macfarlane G.T.: Variation in human intestinal microbiota with age. Dig. Liver Dis., 2002; 34: S12-S18

[10] Claesson M.J., Jeffery I.B., Conde S., Power S.E., O'Connor E.M., Cusack S., Harris H.M., Coakley M., Lakshminarayanan B., O'Sullivan O. i wsp.: Gut microbiota composition correlates with diet and health in the elderly. Nature, 2012; 488: 178-184

[11] Clark R.I. Walker D.W.: Role of gut microbiota in aging-related health decline: Insights from invertebrate models. Cell Mol. Life Sci., 2018; 75: 93-101

[12] Clarke G., O'Mahony S.M., Dinan T.G., Cryan J.F.: Priming for health: Gut microbiota acquired in early life regulates physiology, brain and behaviour. Acta Paediatr., 2014; 103: 812-819

[13] Dogra S., Sakwinska O., Soh S.E., Ngom-Bru C., Brück W.M., Berger B., Brüssow H., Lee Y.S., Yap F., Chong Y.S. i wsp.: Dynamics of infant gut microbiota are influenced by delivery mode and gestational duration and are associated with subsequent adiposity. mBio, 2015; 6: e02419-14

[14] Brinkworth G.D., Noakes M., Clifton P.M., Bird A.R.: Comparative effects of very low-carbohydrate, high-fat and high-carbohydrate, low-fat weight-loss diets on bowel habit and faecal short-chain fatty acids and bacterial populations. Br. J. Nutr., 2009; 101: 14931502

[15] Ticinesi A., Milani C., Lauretani F., Nouvenne A., Mancabelli L., Lugli G.A., Turroni F., Duranti S., Mangifesta M., Viappiani A. i wsp.: Gut microbiota composition is associated with polypharmacy in elderly hospitalized patients. Sci. Rep., 2017; 7: 11102

[16] Stokholm J., Thorsen J., Blaser M.J., Rasmussen M.A., Hjelms $\varnothing$ M., Shah S., Christensen E.D., Chawes B.L., Bønnelykke K., Brix S. i wsp.: Delivery mode and gut microbial changes correlate with an increased risk of childhood asthma. Sci. Transl. Med., 2020; 12: eaax9929

[17] Tropini C., Earle K.A., Huang K.C., Sonnenburg J.L.: The gut microbiome: Connecting spatial organization to function. Cell Host Microbe, 2017; 21: 433-442

[18] Cheng Y., Jin U.H., Allred C.D., Jayaraman A., Chapkin R.S., Safe S.: Aryl hydrocarbon receptor activity of tryptophan metabolites in young adult mouse colonocytes. Drug Metab. Dispos., 2015; 43: 1536-1543

[19] Zelante T., lannitti R,G., Cunha C., De Luca A., Giovannini G., Pieraccini G., Zecchi R., D'Angelo C., Massi-Benedetti C., Fallarino F.: Tryptophan catabolites from microbiota engage aryl hydrocarbon receptor and balance mucosal reactivity via interleukin-22. Immunity, 2013; 39: 372-385

[20] Maranduba C.M., De Castro S.B., de Souza G.T., Rossato C., da Guia F.C., Valente M.A., Rettore J.V., Maranduba C.P., de Souza C.M., do Carmo A.M. i wsp.: Intestinal microbiota as modulators of the immune system and neuroimmune system: Impact on the host health and homeostasis. J. Immunol. Res., 2015; 2015: 931574

[21] Björkholm B., Bok C.M., Lundin A., Rafter J., Hibberd M.L., Pettersson S.: Intestinal microbiota regulate xenobiotic metabolism in the liver. PLoS One, 2009; 4: e6958

[22] Kaur H., Bose C., Mande S.S.: Tryptophan metabolism by gut microbiome and gut-brain-axis: An in silico analysis. Front. Neurosci., 2019; 13: 1365

[23] Ridaura V., Belkaid Y.: Gut microbiota: The link to your second brain. Cell, 2015; 161: 193-194

[24] Reigstad C.S., Salmonson C.E., Rainey J.F.3rd, Szurszewski J.H., Linden D.R., Sonnenburg J.L., Farrugia G., Kashyap P.C.: Gut microbes promote colonic serotonin production through an ef- 
fect of short-chain fatty acids on enterochromaffin cells. FASEB J., 2015; 29: 1395-1403

[25] Vecsey C.G., Hawk J.D., Lattal K.M., Stein J.M., Fabian S.A., Attner M.A., Cabrera S.M., McDonough C.B., Brindle P.K., Abel T., Wood M.A.: Histone deacetylase inhibitors enhance memory and synaptic plasticity via CREB:CBP-dependent transcriptional activation. J. Neurosci. 2007; 27: 6128-6140

[26] Hoyles L., Snelling T., Umlai U.K., Nicholson J.K., Carding S.R., Glen R.C., McArthur S.: Microbiome-host systems interactions: Protective effects of propionate upon the blood-brain barrier. Microbiome, 2018; 6: 55

[27] Kelly J.R., Kennedy P.J., Cryan J.F., Dinan T.G., Clarke G., Hyland N.P.: Breaking down the barriers: The gut microbiome, intestinal permeability and stress-related psychiatric disorders. Front. Cell. Neurosci., 2015; 9: 392

[28] Baothman O.A., Zamzami M.A., Taher I., Abubaker J., Abu-Farha M.: The role of gut microbiota in the development of obesity and diabetes. Lipids Health Dis., 2016; 15: 108

[29] Becker C., Neurath M.F., Wirtz S.: The intestinal microbiota in inflammatory bowel disease. ILAR J., 2015; 56: 192-204

[30] Dahmus J.D., Kotler D.L., Kastenberg D.M., Kistler C.A.: The gut microbiome and colorectal cancer: A review of bacterial pathogenesis. J. Gastrointest. Oncol., 2018; 9: 769-777

[31] Kaur H., Das C., Mande S.S.: In silico analysis of putrefaction pathways in bacteria and its implication in colorectal cancer. Front. Microbiol., 2017; 8: 2166

[32] Hughes R., Magee E.A., Bingham S.: Protein degradation in the large intestine: Relevance to colorectal cancer. Curr. Issues Intest. Microbiol., 2000; 1: 51-58

[33] Toden S., Bird A.R., Topping D.L., Conlon M.A.: Resistant starch attenuates colonic DNA damage induced by higher dietary protein in rats. Nutr. Cancer, 2005; 51: 45-51

[34] Shen W., Gaskins H.R., Mclntosh M.K.: Influence of dietary fat on intestinal microbes, inflammation, barrier function and metabolic outcomes. J. Nutr. Biochem., 2014; 25: 270-280

[35] Nakamura J., Kubota Y., Miyaoka M., Saitoh T., Mizuno F, Benno Y.: Comparison of four microbial enzymes in Clostridia and Bacteroides isolated from human feces. Microbiol. Immunol., 2002; 46: 487-490

[36] Pollet R.M., D'Agostino E.H., Walton W.G., Xu Y., Little M.S., Biernat K.A., Pellock S.J., Patterson L.M., Creekmore B.C., Isenberg H.N., i wsp.: An atlas of $\beta$-glucuronidases in the human intestinal microbiome. Structure, 2017; 25: 967-977

[37] Vila A.V., Collij V., Sanna S., Sinha T., Imhann F., Bourgonje A.R., Mujagic Z., Jonkers D.M., Masclee A.A., Fu J. i wsp.: Impact of commonly used drugs on the composition and metabolic function of the gut microbiota. Nat. Commun., 2020; 11: 362

[38] Finlayson-Trick E.C., Fischer J.A., Goldfarb D.M., Karakochuk C.D.: The effects of iron supplementation and fortification on the gut microbiota: A review. Gastrointest. Disord., 2020; 2: 327-340

[39] Skonieczna-Żydecka K., Łoniewski I., Misera A., Stachowska
E., Maciejewska D., Marlicz W., Galling B.: Second-generation antipsychotics and metabolism alterations: A systematic review of the role of the gut microbiome. Psychopharmacology, 2019; 236: 1491-1512

[40] Zhang S., Chen D.C.: Facing a new challenge: The adverse effects of antibiotics on gut microbiota and host immunity. Chin. Med. J., 2019; 132: 1135-1138

[41] Ponziani F.R., Zocco M.A., D'Aversa F., Pompili M., Gasbarrini A.: Eubiotic properties of rifaximin: Disruption of the traditional concepts in gut microbiota modulation. World J. Gastroenterol., 2017; 23: 4491-4499

[42] Imhann F., Bonder M.J., Vila A.V., Fu J., Mujagic Z., Vork L., Tigchelaar E.F., Jankipersadsing S.A., Cenit M.C., Harmsen H.J. i wsp.: Proton pump inhibitors affect the gut microbiome. Gut, 2016; 65: $740-748$

[43] Jackson M.A., Goodrich J.K., Maxan M-E., Freedberg D.E., Abrams J.A., Poole A.C., Sutter J.L., Welter D., Ley R.E., Bell J.T. i wsp.: Proton pump inhibitors alter the composition of the gut microbiota. Gut, 2016; 65: 749-756

[44] Moayyedi P., Eikelboom J.W., Bosch J., Connolly S.J., Dyal L., Shestakovska O., Leong D., Anand S.S., Störk S., Branch K.R i wsp.: Safety of proton pump inhibitors based on a large, multiyear, randomized trial of patients receiving rivaroxaban or aspirin Gastroenterology, 2019; 157: 682-691

[45] Yepuri G., Sukhovershin R., Nazari-Shafti T.Z., Petrascheck M., Ghebre Y.T., Cooke J.P.: Proton pump inhibitors accelerate endothelial senescence. Circ. Res., 2016; 118: e36-e42

[46] Forslund K., Hildebrand F., Nielsen T., Falony G., Le Chatelier E., Sunagawa S., Prifti E., Vieira-Silva S., Gudmundsdottir V., Krogh Pedersen $\mathrm{H}$. i wsp.: Disentangling type 2 diabetes and metformin treatment signatures in the human gut microbiota. Nature, 2015; 528: $262-266$

[47] Wu H., Esteve E., Tremaroli V., Khan M.T., Caesar R., ManneråsHolm L., Ståhlman M., Olsson L.M., Serino M., Planas- Fèlix M. i wsp.: Metformin alters the gut microbiome of individuals with treatment-naive type 2 diabetes, contributing to the therapeutic effects of the drug. Nat. Med., 2017; 23: 850-858

[48] Vieira-Silva S., Falony G., Belda E., Nielsen T., Aron-Wisnewsky J., Chakaroun R., Forslund S., Assmann K., Valles-Colomer M., Nguyen T.T. i wsp.: Statin therapy is associated with lower prevalence of gut microbiota dysbiosis. Nature, 2020; 581: 310-315

[49] Noh K., Kang Y.R., Nepal M.R., Shakya R., Kang M.J., Kang W., Lee S., Jeong H.G., Jeong T.C.: Impact of gut microbiota on drug metabolism: An update for safe and effective use of drugs. Arch. Pharm. Res., 2017; 40: 1345-1355

[50] Lauschke V.M., Ingelman-Sundberg M.: Prediction of drug response and adverse drug reactions: From twin studies to Next Generation Sequencing. Eur. J. Pharm. Sci., 2019; 130: 65-77

[51] Sharma A., Buschmann M.M., Gilbert J.A.: Pharmacomicrobiomics: The holy grail to variability in drug response? Clin. Pharmacol. Ther., 2019; 106: 317-328 
[52] Claesson M.J., Clooney A.G., O'Toole P.W.: A clinician's guide to microbiome analysis. Nat. Rev. Gastroenterol. Hepatol., 2017; 14: $585-595$

[53] Davenport E.R., Sanders J.G., Song S.J., Amato K.R., Clark A.G., Knight R.: The human microbiome in evolution. BMC Biol., 2017; 15: 127

[54] Arkhipova O.V., Akimenko V.K.: Unsaturated organic acids as terminal electron acceptors for reductase chains of anaerobic bacteria. Mikrobiologiia, 2005; 74: 725-737

[55] Koppel N., Rekdal V.M., Balskus E.P.: Chemical transformation of xenobiotics by the human gut microbiota. Science, 2017; 356: $1246-1257$

[56] Clarke G., Sandhu K.V., Griffin B.T., Dinan T.G., Cryan J.F., Hyland N.P.: Gut reactions: Breaking down xenobiotic-microbiome interactions. Pharmacol. Rev., 2019; 71: 198-224

[57] Gopalakrishnan V., Spencer C.N., Nezi L., Reuben A., Andrews M.C., Karpinets T.V., Prieto P.A., Vicente D., Hoffman K., Wei S.C. i wsp.: Gut microbiome modulates response to anti-PD-1 immunotherapy in melanoma patients. Science, 2018; 359: 97-103

[58] Routy B., Le Chatelier E., Derosa L., Duong C.P., Alou M.T., Daillère R., Fluckiger A., Messaoudene M., Rauber C., Roberti M.P. i wsp.: Gut microbiome influences efficacy of PD-1-based immunotherapy against epithelial tumors. Science, 2018; 359: 91-97

[59] Hubbard T.D., Murray I.A., Perdew G.H.: Indole and tryptophan metabolism: Endogenous and dietary routes to Ah receptor activation. Drug Metab. Dispos., 2015; 43: 1522-1535

[60] Jin U.H., Lee S.O., Sridharan G., Lee K., Davidson L.A., Jayaraman A., Chapkin R.S., Alaniz R., Safe S.: Microbiome-derived tryptophan metabolites and their aryl hydrocarbon receptor-dependent agonist and antagonist activities. Mol. Pharmacol., 2014; 85: $777-788$

[61] Venkatesh M., Mukherjee S., Wang H., Li H., Sun K., Benechet A.P., Qu Z., Maher L., Redinbo M.R., Phillips R.S. i wsp.: Symbiotic bacterial metabolites regulate gastrointestinal barrier function via the xenobiotic sensor PXR and Toll-like receptor 4. Immunity, 2014; 41: 296-310

[62] Wallace B.D., Redinbo M.R.: Xenobiotic-sensing nuclear receptors involved in drug metabolism: A structural perspective. Drug Metab. Rev., 2013; 45: 79-100

[63] Lee S.H., An J.H., Lee H.J., Jung B.H.: Evaluation of pharmacokinetic differences of acetaminophen in pseudo germ-free rats. Biopharm. Drug Dispos., 2012; 33: 292-303

[64] Li H., He J., Jia W.: The influence of gut microbiota on drug metabolism and toxicity. Expert Opin. Drug. Metab. Toxicol., 2016; 12: $31-40$

[65] Possamai L.A., McPhail M.J., Khamri W., Wu B., Concas D., Harrison M., Williams R., Cox R.D., Cox I.J., Anstee Q.M., Thursz M.R.: The role of intestinal microbiota in murine models of acetaminophen-induced hepatotoxicity. Liver Int., 2015; 35: 764-773

[66] Sousa T., Yadav V., Zann V., Borde A., Abrahamsson B., Basit A.W.: On the colonic bacterial metabolism of azo-bonded prodrugs of 5-aminosalicylic acid. J. Pharm. Sci., 2014; 103: 3171-3175
[67] Deloménie C., Fouix S., Longuemaux S., Brahimi N., Bizet C., Picard B., Denamur E., Dupret J.M.: Identification and functional characterization of arylamine $\mathrm{N}$-acetyltransferases in eubacteria: Evidence for highly selective acetylation of 5-aminosalicylic acid. J. Bacteriol., 2001; 183: 3417-3427

[68] Kaddurah-Daouk R., Baillie R.A., Zhu H., Zeng Z.B., Wiest M.M, Nguyen U.T., Wojnoonski K., Watkins S.M, Trupp M., Krauss R.M.: Enteric microbiome metabolites correlate with response to simvastatin treatment. PLoS One, 2011; 6: e 25482

[69] Yoo D.H., Kim I.S., Van Le T.K., Jung I.H., Yoo H.H., Kim D.H.: Gut microbiota-mediated drug interactions between lovastatin and antibiotics. Drug Metab. Dispos., 2014; 42: 1508-1513

[70] Viaud S., Flament C., Zoubir M., Pautier P., LeCesne A., Ribrag V., Soria J.C., Marty V., Vielh P., Robert C. i wsp.: Cyclophosphamide induces differentiation of Th17 cells in cancer patients. Cancer Res. 2011; 71: 661-665

[71] Viaud S., Saccheri F., Mignot G., Yamazaki T., Daillère R., Hannani D., Enot D.P., Pfirschke C., Engblom C., Pittet M.J. i wsp.: The intestinal microbiota modulates the anticancer immune effects of cyclophosphamide. Science, 2013; 342: 971-976

[72] Roberts A.B., Wallace B.D., Venkatesh M.K., Mani S., Redinbo M.R.: Molecular insights into microbial $\beta$-glucuronidase inhibition to abrogate CPT-11 toxicity. Mol. Pharmacol., 2013; 84: 208-217

[73] Saitta K.S., Zhang C., Lee K.K., Fujimoto K., Redinbo M.R., Boelsterli U.A.: Bacterial $\beta$-glucuronidase inhibition protects mice against enteropathy induced by indomethacin, ketoprofen or diclofenac: Mode of action and pharmacokinetics. Xenobiotica, 2014; 44: 28-35

[74] Choi M.S., Yu J.S., Yoo H.H., Kim D.H.: The role of gut microbiota in the pharmacokinetics of antihypertensive drugs. Pharmacol. Res., 2018; 130: 164-171

[75] Haiser H.J., Gootenberg D.B., Chatman K., Sirasani G., Balskus E.P., Turnbaugh P.J.: Predicting and manipulating cardiac drug inactivation by the human gut bacterium Eggerthella lenta. Science, 2013; 341: 295-298

[76] Haiser H.J., Seim K.L., Balskus E.P., Turnbaugh P.J.: Mechanistic insight into digoxin inactivation by Eggerthella lenta augments our understanding of its pharmacokinetics. Gut Microbes, 2014; 5: $233-238$

[77] Kumar K., Jaiswal S.K., Dhoke G.V., Srivastava G.N., Sharma A.K., Sharma V.K.: Mechanistic and structural insight into promiscuity based metabolism of cardiac drug digoxin by gut microbial enzyme. J. Cell. Biochem., 2018; 119: 5287-5296

[78] Hashim H., Azmin S., Razlan H., Yahya N.W., Tan H.J., Manaf M.R., Ibrahim N.M.: Eradication of Helicobacter pylori infection improves levodopa action, clinical symptoms and quality of life in patients with Parkinson's disease. PLoS One, 2014; 9: e112330

[79] Matuskova Z., Anzenbacher P., Vecera R., Siller M., TlaskalovaHogenova H., Strojil J., Anzenbacherova E.: Effect of Lactobacillus casei on the pharmacokinetics of amiodarone in male Wistar rats. Eur. J. Drug Metab. Pharmacokinet., 2017; 42: 29-36

[80] Nakayama H., Kinouchi T., Kataoka K., Akimoto S., Matsuda Y., 
Ohnishi Y.: Intestinal anaerobic bacteria hydrolyse sorivudine, producing the high blood concentration of 5-(E)-(2-bromovinyl)uracil that increases the level and toxicity of 5 -fluorouracil. Pharmacogenetics, 1997; 7: 35-43

[81] Okuda H., Ogura K., Kato A., Takubo H., Watabe T.: A possible mechanism of eighteen patient deaths caused by interactions of sorivudine, a new antiviral drug, with oral 5-fluorouracil prodrugs. J. Pharmacol. Exp. Ther., 1998; 287: 791-799

[82] Poteres E., Hubert N., Poludasu S., Brigando G., Moore J., Keeler K., Isabelli A., Ibay I.C., Alt L., Pytynia M. i wsp.: Selective regional alteration of the gut microbiota by diet and antibiotics. Front. Physiol., 2020; 11: 797
[83] Stojančević M., Bojić G., Salami H.A., Mikov M.: The influence of intestinal tract and probiotics on the fate of orally administered drugs. Curr. Issues Mol. Biol., 2014; 16: 55-68

[84] Zeevi D., Korem T., Zmora N., Israeli D., Rothschild D., Weinberger A., Ben-Yacov O., Lador D., Avnit-Sagi T., Lotan-Pompan M. i wsp.: Personalized nutrition by prediction of glycemic responses. Cell, 2015; 163: 1079-1094

[85] Wallace B.D., Roberts A.B., Pollet R.M., Ingle J.D., Biernat K.A., Pellock S.J., Venkatesh M.K., Guthrie L., O'Neal S.K., Robinson S.J. i wsp.: Structure and inhibition of microbiome $\beta$-glucuronidases essential to the alleviation of cancer drug toxicity. Chem. Biol., 2015; 22: 1238-1249 